\title{
Jurastuderendes læring via deres aktive arbejde med stoffet
}

\author{
Pernille Rattleff, cand.polit., ph.d., lektor ved Det Juridiske Fakultet, Kфbenhavns \\ Universitet.
}

Den 1. september 2011 trådte Studieordning 2011 for den juridiske bachelor- og kandidatuddannelse ved Det Juridiske Fakultet på Københavns Universitet $i$ kraft. I den forbindelse er Det Juridiske Fakultet ved at gennemføre en omfattende og grundlæggende pxdagogisk reform af det juridiske studium, der med et optag på godt 800 studerende pr. september 2012 er Danmarks største bacheloruddannelse. Et helt centralt element $i$ denne studiereform er, at de studerende skal arbejde aktivt med stoffet - både forud for, i løbet af og efter den skemasatte undervisning. Denne artikel handler om de studerendes læringsmæssige udbytte af aktivt arbejde med stoffet, idet empiriske undersøgelser af de studerendes adfrrd og læring tyder $p a ̊$, at de studerende med studiereformen $i$ højere grad end tidligere er forberedte til og tager aktivt og engageret del i undervisning. Tidligere havde de studerende - med megen monologisk undervisning og udenadslære - bedre overblik over stoffet, var mere detailorienterede og havde mere paratviden. De nye studerende er imidlertid bedre til at argumentere og formulere sig, og har desuden en bedre forståelse af det lærte, lige som de $i$ højere grad kan anvende det larte.

\section{Introduktion: Studiereformen af den juridiske bachelor- og kandidatuddannelse Tidligere var undervisningen på den juridiske bacheloruddannelse traditionelt tilret- telagt med megen monologisk undervisning - herunder mange forelæsninger for flere end 200 studerende. $^{1}$}

Tilbagemeldinger fra aftagere og censorer ${ }^{2}$ om de færdige kandidaters faglige niveau med fokus på udenadslære og detailviden frem for dybere forståelse, anvendelse og metode peger imidlertid på, at denne form for monologisk undervisning ikke er velegnet til at sikre, at de færdige juridiske kandidater kan matche arbejdsmarkedets behov for kandidater, der ikke blot har viden og analytiske færdigheder men også

1 I faget "Forvaltningsret" (15 ECTS-point) på den tidligere 2006 studieordning havde de studerende eksempelvis 49 undervisningsgange (hver af to lektioners varighed), hvoraf 22 undervisningsgange var forelæsninger, mens de resterende 27 var undervisning på manuduktionshold.

2 Jf. tilbagemeldinger fra censorer ved Det Juridiske Fakultets sommereksaminer 2011. 
har kompetencerne til at håndtere usikkerhed og kompleksitet, til at formidle, kommunikere og samarbejde med både fagfæller og ikke-fagfæller og til - helt afgørende - at kunne identificere, analysere, ræsonnere, argumentere og formulere løsningsforslag til løsning af nye problemer på adækvate måder.

Studiereformen bunder således dels i konkrete tilbagemeldinger fra aftagere og censorer, dels i ønsket om at sikre, at de færdige kandidater kan matche arbejdsmarkedets krav.

Et helt centralt element i studiereformen er, at de studerende skal arbejde aktivt med stoffet - både forud for, i løbet af og efter den skemasatte undervisning - ud fra forestillingen om, at "Det er den, der arbejder, der lærer noget," som dr. pæd. Steen Larsen udtrykker det i 'Bedstes Lov'3 (Larsen, 1998, s. 37).

De studerendes aktive arbejde med stoffet sikres ved: Diskuterende, dialogisk undervisning på mindre seminarhold, etablering af studiegrupper, brug af gruppevejledere (ældre jurastuderende) som facilitatorer, skemasatte timer til forberedelse, formulering af læringsmål samt oplæg til studerendes individuelle og gruppebaserede forberedelse til og efterbehandling af undervisningen.

Med studiereformen foregår undervisning overvejende på mindre, såkaldte seminarhold med maksimalt 28 studerende pr. hold. ${ }^{4}$ De studerende er i en vis forstand kommet tæt på underviserne.

I begrænset omfang suppleres undervisningen på seminarholdene med traditionelle, overbliksskabende forelæsninger for op imod 200 studerende. ${ }^{5}$

Fra studiestart arbejder de studerende i studiegrupper med 5-7 studerende i hver gruppe, og hvert seminarhold har skemasatte kontakttimer med en gruppevejleder, der understøtter og faciliterer de studerendes samarbejde i studiegrupperne, såvel som bistår de studerende med faglige spørgsmål.

De studerende har desuden skemasatte timer til individuel og fælles forberedelse til undervisningen i fagene således, at de studerende har skemasat en fuld arbejdsuge med en blanding af undervisning, kontakttimer med gruppevejlederne og forberedelse.

3 'Bedstes Lov' er formuleret af Larsens bedstemor - deraf navnet.

4 Med studiereformen er der 37 undervisningsgange pr. semester pr. bachelorfag (på 10 ECTS-point). Hver undervisningsgang er af to lektioners varighed. De 34 undervisningsgange er undervisning på seminarholdene, mens der kun er tre forelæsninger.

5 Med studiereformen er kun tre ud af 37 undervisningsgange på et 10 ECTS-point bachelorfag forelæsninger, mens de resterende 34 undervisningsgange er undervisning på seminarholdene. 
På den nye studieordning følger de studerende et nyt fag på 1. semester - "Studieteknik og læringsproces" - på 2,5 ECTS-point. Formålet med dette fag er blandt andet at hjælpe de studerende til at blive selvstændige universitetsstuderende, der kan arbejde professionelt sammen - også i nye sammenhænge.

Jf. "Bologna-deklarationen"6 (vedtaget af EU-landene i 1999) og "Kvalifikationsrammen for Livslang Læring" 7 definerer underviserne på Det Juridiske Fakultet $l æ x-$ ringsmål - for de enkelte fag såvel som for hver enkelt undervisningsgang:

Der har i de senere år været en bevægelse i uddannelsessystemet fra formulering af pensum til formulering af kompetence. Det centrale i et moderne videnssamfund er ikke mere eller mindre ureflekteret viden, men evnen til at anvende viden både som konkrete færdigheder og som kompetencer, der kan anvendes i nye kontekster. (Andersen \& Tofteskov, 2010, s. 35).

Jf. kvalifikationsrammen formulerer underviserne ved Det Juridiske Fakultet læringsmål for den viden, de færdigheder henholdsvis de kompetencer, de studerende forventes at have erhvervet sig i det pågældende fag og efter den pågældende undervisningsgang.

Man kan sige, at viden svarer til de to laveste niveauer - vidensniveauet og forståelsesniveauet - i Blooms taksonomi ${ }^{8}$, fxrdigheder svarer til anvendelsesniveauet, mens kompetencer svarer til analyse, syntese og vurdering, de såkaldte 'higher order skills', i taksonomien.

Underviserne formulerer oplæg til individuel såvel som gruppebaseret forberedelse til hver undervisningsgang og oplæg til efterbehandling af undervisningen i studiegrupperne, hvor de studerende diskuterer et eller flere spørgsmål, der skal hjælpe de studerende med at få det, de har lært, arbejdet meningsfyldt på plads.

6 Jf. Ministeriet for Forskning, Innovation og Videregående Uddannelser, Styrelsen for Universiteter og Internationalisering, http://www.iu.dk/politiske-rammer/bologna-processen

7 Kvalifikationsrammen for Livslang Læring er formuleret af Styrelsen for Universiteter og Internationalisering under Ministeriet for Forskning, Innovation og Videregående Uddannelser og kan findes her: http://www.iu.dk/dokumentation/kvalifikationsrammer.

8 Blooms Taxonomy of Educational Objectives (Bloom et al., 1956) skelner som bekendt mellem 'lower' og 'higher order skills'. 'Lower order skills' er viden, forståelse og anvendelse, mens 'higher order skills' er analyse, syntese og vurdering. 


\section{Resultater': Studerendes læring via deres aktive arbejde med stoffet}

Det er almindeligt kendt, at studerende (udelukkende) lærer sig det, de skal kunne til eksamen (Andersen \& Tofteskov, 2010, s. 28). Jurastuderende er ingen undtagelse, og samtidig er de jurastuderende særdeles pensum- og eksamensorienterede; til en indledende forelæsning i første semesters faget "Strafferet" om implementeringen af de to danske terrorpakker i 2002 og 2006 bemærkede hele $40 \%$ af de deltagende studerende ${ }^{10}$ således uopfordret, at dagens emne ikke var pensum.

Det er derfor afgørende, at der er overensstemmelse (alignment ${ }^{11}$ ) mellem fagets læringsmål og fagets eksamen, da de studerende ellers ikke når læringsmålene, men udelukkende fokuserer på og derved udelukkende lærer sig det, de skal kunne til eksamen.

Tidligere har jurastuderende haft en tendens til detailorienteret udenadslære; på en hjemmeside for jurastuderende ${ }^{12}$ ved Aarhus Universitet kan man eksempelvis læse:

Mundtlige eksaminer på jura-studiet giver de studerende mulighed, for at prøve kræfter udi den klassiske disciplin, udenadslære. Man bliver nemlig eksamineret i lærebogens kapitler (i hovedsagen svarer ét kapitel til ét eksamensspørgsmål), som man uden forberedelse skal kunne referere. Det foregår ved at lære x-antal dispositioner udenad i løbet af læseferien. (Fournais, 2012).

En juridisk kandidat fra Københavns Universitet siger tilsvarende: "Så starter man bare båndoptageren."13

Problemet med denne udenadslære er imidlertid, at:

- "Man har glemt det hele, når eksamen er overstået."14

- "Vi glemmer det jo bare tre dage efter. Det betyder jo ikke noget."15

9 Resultaterne i denne artikel er formuleret på baggrund af drøftelser med studerende og undervisere samt observation af undervisning. Jeg har drøftet artiklens resultater og konklusioner med nuværende såvel som tidligere studerende, fagledere, undervisere - interne såvel som eksterne - og aftagere og censorer, der dels selv er uddannet jurister, dels har været tilknyttet som censorer i en menneskealder; alle giver samstemmende udtryk for, at det er et udmærket og rammende billede, jeg tegner.

10 Til forelæsningen (30. september 2011) var der i alt 160 studerende, der efter forelæsningen deltog i undersøgelsen ved at udfylde og aflevere et spørgeskema om undervisningen.

11 Dette begreb er hentet fra den amerikanske læringsteoretiker John Biggs (2003).

12 http://www.studjur.dk/content/omjura/fagene.html

13 Udsagnet blev fremført af en juridisk kandidat, som jeg drøftede eksamensformer med - her konkret den mundtlige eksamen - ved et møde (8. marts 2012).

14 Udsagn fra færdig juridisk kandidat ved møde (27. april 2012).

15 Udsagn fra en jurastud. ansat som gruppevejleder, på møde med gruppevejlederne (efteråret 2011). 
I forlængelse heraf fremfører en anden studerende ${ }^{16}$, at Det Juridiske Fakultet stiller store krav til studerende på den nye studieordning med formuleringen af læringsmål for, hvad de nye studerende skal lære og kunne: "Jeg er bare vant til at lære en bog udenad."

De nye førsteårsstuderende tilkendegiver imidlertid ${ }^{17}$, at: "Læringsmål fungerer rigtig, rigtig godt, så ved jeg, hvad jeg skal have ud af det."

I forlængelse heraf tilkendegiver underviserne ${ }^{18}$, at det i tilknytning til læringsmålene er vigtigt at eksplicitere, hvad de studerende har lært (eksempelvis at identificere et retligt problem), fordi de studerende ikke nødvendigvis selv kan formulere, hvad de præcist har lært - eksempelvis af at læse og arbejde med en case. De studerende har således brug for at få italesat, hvori deres læring præcist består.

Nogle studerende har været (meget) skeptiske over for organiseringen af de studerende i studiegrupper, men oplæg til den fælles forberedelse i studiegrupperne ser ud til at virke, idet underviserne således tilkendegiver ${ }^{19}$, at de studerende generelt møder forberedte op til undervisningen.

En underviser siger ${ }^{20}$ tilsvarende om de jurastuderendes tidligere praksis, hvor (mange) studerende kom (mere eller mindre) uforberedte til undervisning og først læste pensum op i forbindelse med eksamen: "Før i tiden kunne man jo komme igennem et halvt år uden at have læst en side eller en dom, det går jo ikke mere."

Underviserne fremfører ${ }^{21}$, at de studerendes arbejde med stoffet i deres individuelle og studiegruppebaserede forberedelse desuden fører til, at de studerende får en meget bedre forståelse af stoffet, al den stund, at de studerende ikke blot læser men også diskuterer stoffet.

Undervisning på de mindre seminarhold giver mulighed for dialog og diskussion. De studerende er meget aktive, engagerede og diskussionslystne på seminarholdene.

16 Udsagn fra en jurastuderende ansat som gruppevejleder, på møde med gruppevejlederne (efteråret 2011).

17 Udsagn fra studerende på første år på holdrepræsentantskabsmøde (28. oktober 2011) med deltagelse af studenterrepræsentanter fra alle seminarholdene på første år.

18 Udsagn fra underviser ved gruppeinterview (26. marts 2011) med deltagelse af syv undervisere fra alle fagene på første studieår.

19 Udsagn fra undervisere på erfaringsudvekslingsmøder (28. november og 1. december 2011) med undervisere på første studieår og ved gruppeinterviewet med undervisere på førsteårsfagene (26. marts 2012).

20 Udsagn fra underviser ved gruppeinterviewet (26. marts 2011).

21 Udsagn fra underviser ved gruppeinterviewet (26. marts 2011). 
Dette fører til, at man som underviser kan have "faglig dialog med de studerende på et meget højt niveau." 22

Fagleder og professor Ole Hansen konkluderer videre om undervisningen i faget "Erstatning og kontrakt" på seminarhold i første semester: "Rollen som underviser er fuldkommen anderledes, klart blevet mere krævende."

Dette hænger - ifølge Hansen - sammen med, at de studerende i efteråret 2011 var velforberedte (i modsætning til tidligere, hvor de studerende kun havde forberedt sig de første seks uger), de studerende var krævende og fantastisk engagerede - hvor de studerende tidligere var uengagerede med vigende fremmøde i løbet af semestret.

En underviser siger ${ }^{23}$ tilsvarende, at de studerende tidligere forventede, at "man gjorde alt for dem."

En vigtig pointe er, at de studerende - qua deres eget arbejde med eksempelvis at drøfte spørgsmål og diskussion af cases i deres forberedelse - for det første forstår (og husker) stoffet bedre og for det andet er blevet bedre til at anvende det lærte.

Fagleder Ole Hansen taler om, at de studerende nu lærer noget, hvor de tidligere indsamlede og copy-pastede standardbegrundelser. Hansen taler ligefrem om et "skift fra paratviden til forståelse".

Det samme gør underviserne ${ }^{24}$ på førsteårsfagene; de studerendes aktive arbejde med stoffet i deres individuelle og studiegruppebaserede forberedelse fører til, at de studerende får en meget bedre forståelse af stoffet - til gengæld er der nogle detaljer, de mangler, de studerende har mindre paratviden, "de kan ikke lige lire 5 domme af sig".

De studerendes bedre forståelse hænger sammen med, at de "hurtigt bliver tvunget til at arbejde med tingene i stedet for bare at læse det - uden at forstå det."25

I nedenstående figur 1 har jeg søgt at illustrere den bevægelse i de jurastuderende læring, der tilsyneladende følger af, at de studerende arbejder aktivt med stoffet.

22 Udsagnet blev fremført af professor Ole Hansen, der tidligere har undervist i "Formueret I" og i efteråret 2011 var fagleder af, forelæser og seminarholdsunderviser på det formueretlige førstesemestersfag "Erstatning og kontrakt". Dette og de efterfølgende udsagn blev fremført i et oplæg på Det Juridiske Fakultets censordag 15. marts 2012, hvor Ole Hansen gjorde rede for erfaringerne fra efterårets undervisning i "Erstatning og kontrakt".

23 Udsagn fra underviser ved gruppeinterviewet (26. marts 2011).

24 Kilde: Gruppeinterviewet med undervisere på førsteårsfagene (26. marts 2012).

25 Udsagn fra underviser ved gruppeinterviewet (26. marts 2011). 
Figur 1. En model for skiftet $i$ de jurastuderendes læring som følge af de studerendes aktive arbejde med stoffet.

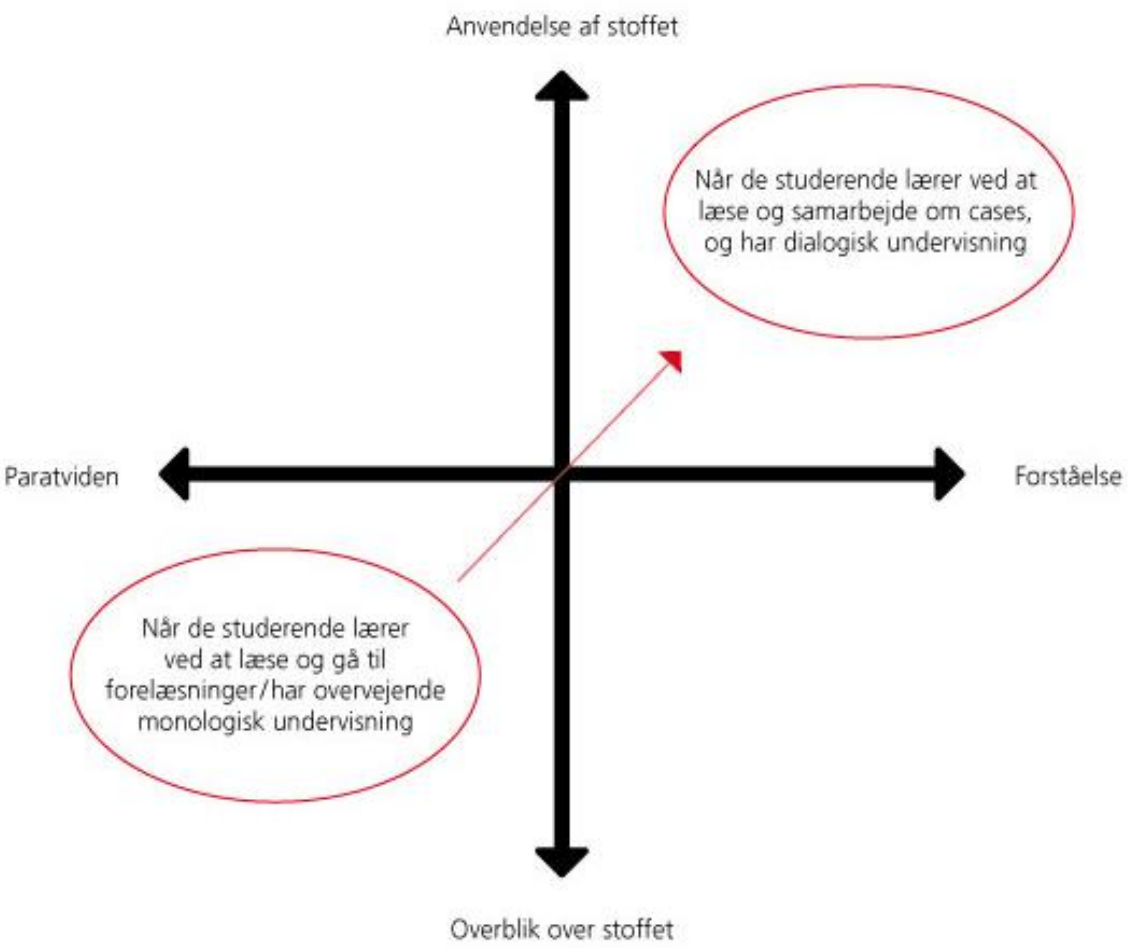

Kilde: Egen tilvirkning baseret på observation af undervisning og drøftelser med undervisere på den tidligere (2006) og den nye (2011) Studieordning for den juridiske bachelor- og kandidatuddannelse.

Når de studerende arbejder med konkrete cases, forstår de imidlertid ikke nødvendigvis meningen med casen, hvad casen skal illustrere. De studerende kan således godt analysere og forholde sig til den konkrete case uden at forstå, hvordan casen hænger sammen med det overordnede, med generelle betragtninger vedrørende gældende ret og med de bagvedliggende hensyn.

Da jeg var ansat som pædagogisk konsulent på Danmarks Tekniske Universitet (DTU), observerede jeg ad flere omgange (i foråret 2008 og igen i foråret 2010) et kursus i eksperimentel biokemi, mere specifikt en øvelse om udvinding af glykogen fra rottelever. ${ }^{26}$

Når jeg observerede de studerende i laboratoriet og efterfølgende spurgte dem, hvad de havde gjort i laboratoriet, forklarede de, at de havde snittet rottelever og udvundet glykogen. Når jeg spurgte, hvorfor de havde udvundet glykogen, hvad meningen således var med øvelsen, svarede de, at det havde de ikke rigtig sat sig ind i endnu.

26 Nedenstående udsagn stammer fra observation og interviews i forbindelse med denne øvelse. 
Når jeg spurgte underviseren, hvad de studerende havde lært i laboratoriet af glykogenøvelsen var svaret (temmelig overraskende): "De studerende har lært, hvordan den menneskelige organisme udvinder energi fra kulhydrater."

Denne forståelse udsprang imidlertid ikke af det eksperimentelle laboratoriearbejde, men kom i stand via undervisernes eftervejledning i forbindelse med de studerendes arbejde med og bearbejdning af deres resultater. Først via dette arbejde og vejledningen i forbindelse hermed blev det klart for de studerende, hvad meningen var med den konkrete laboratorieøvelse.

Ligesom underviserne på DTU skal sikre, at de studerende forstår meningen med det eksperimentelle arbejde, skal underviserne på jurastudiet sætte arbejdet med konkrete cases ind i en overordnet og meningsfuld sammenhæng; det er afgørende, at underviserne sikrer, at de studerende forstår, hvad en konkret case illustrerer.

\section{Diskussion: Udenadslære kontra meningsfuld læring}

Der findes mange teorier om og definitioner af læring (jf. fx Rattleff, 2001, s. 45-51), men fælles for flere definitioner (fx Ellström, 1992, s. 67; Grue-Sørensen, 1974, s. 198; Guilford, 1967, s. 268; Voksenpædagogisk Opslagsbog, 1998) er deres betoning af læring som forandring; den, der har lært sig noget, er forandret og ved, forstår, kan eller gør derfor noget anderledes, end før vedkommende havde lært sig dette nye.

Flere definitioner (fx Ellström, 1992, s. 67; Jarvis, 1990, s. 196) peger endvidere på, at der skal være tale om relativt varige forandringer, før man vil tale om læring.

Hos den engelske læringsteoretiker Peter Jarvis har alle situationer et læringspotentiale, og Jarvis skelner (1992, s. 71-78) mellem ikke-læring, ikke-refleksiv læring henholdsvis refleksiv læring som mulige resultater af sådanne situationer. En særlig form for ikke-refleksiv læring er udenadslæren, der ganske vist er læring, men hvis udenadslære er det eneste element i læreprocessen, efterlader dette blot personen "styrket men relativt uforandret" (Wahlgren et al., 2002, s. 147).

Inden for rammerne af Jarvis' model for læring kan man derved diskutere, om udenadslære fører til læring i betydningen relativt varige forandringer af et individs kompetencer med hensyn til at vide, forstå, kunne eller blot gøre noget anderledes end forud for denne udenadslære. I modsætning til udenadslære fører de jurastuderendes aktive arbejde med stoffet indenfor rammerne af Jarvis' model til, at de studerende desuden ræsonnerer og reflekterer, evaluerer og eksperimenterer, hvilket fører til, at de studerende kommer ud af læreprocessen som mere erfarne, mere vidende.

Uddannelsespsykologer (fx Ausubel et al., 1978, s. 22ff.) skelner i tilknytning hertil mellem det, der skal læres, og den måde, det, der skal læres, læres på.

I figur 2 nedenfor vedrører x-aksen det, der skal læres, mens y-aksen vedrører måden, det læres på. 
Det fremgår, at x-aksen går fra, at det, der skal læres, er et fast pensum ${ }^{27}$ til, at der er tale om reel autonomi i læringssituationen. Midtimellem findes 'tilsyneladende autonomi med skjulte bindinger', hvor megen skolastisk læring hører til - eksempelvis arbejde i det såkaldte 'kogebogslaboratorium'28, hvor elever og studerende i mange tilfælde blot skal eftervise lovmæssigheder.

De skjulte bindinger kommer til udtryk derved, at de studerende skal gøre og lære noget bestemt - ikke et bestemt, givent pensum - men dog noget bestemt, inden for bestemte emneområder og/eller nå til bestemte erkendelser. De har således ikke reel autonomi til at vælge, hvad de gerne vil undersøge, udforske og lære.

Figurens y-akse går fra udenadslære til meningsfuld læring.

Figur 2. Typer af læring.

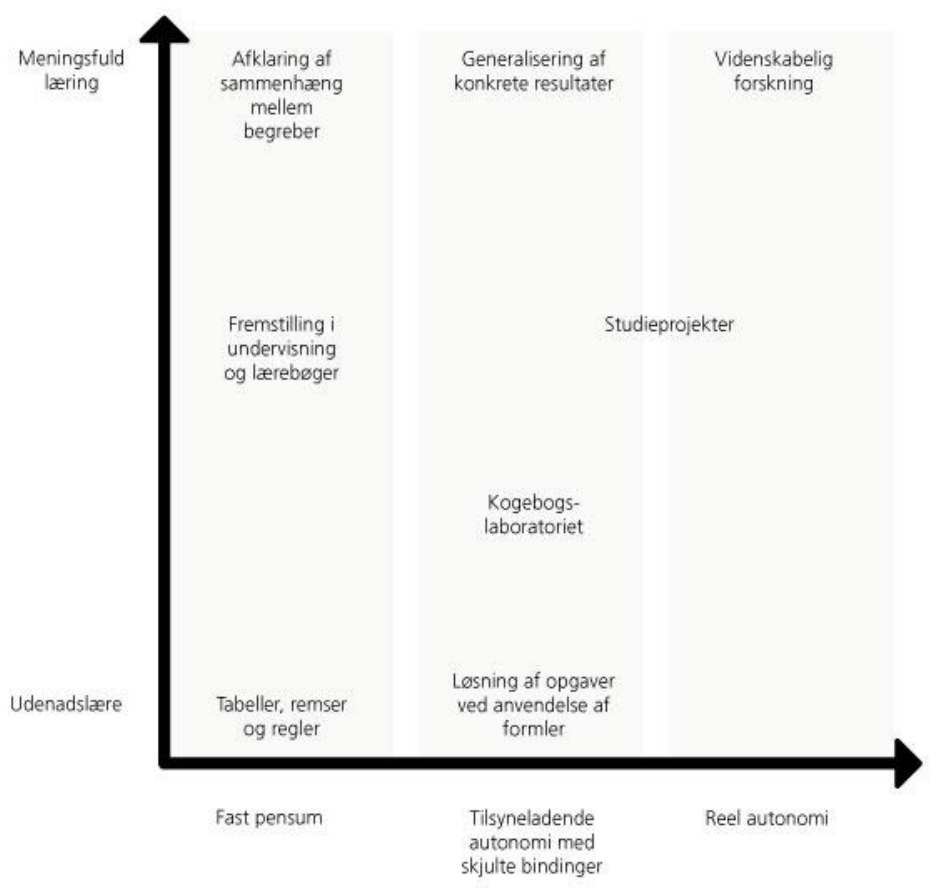

Kilde: Egen tilvirkning med udgangspunkt i Ausubel et al. (1978, s. 25).

Udenadslære har imidlertid ingen (nævneværdig) transferværdi (jf. fx Ausubel, 1968, s. 161). Den kan udelukkende gengives, kan ikke bruges, og da slet ikke i nye sammenhænge.

27 Termerne 'Fast pensum', 'Tilsyneladende autonomi med skjulte bindinger' og 'Reel autonomi' er hentet fra Jacobsen $(1989$, s. 47; 73; 78). Ausubel et. al.'s oprindelige betegnelser er 'Reception learning', 'Guided discovery learning' hhv. 'Autonomous discovery learning' (jf. Ausubel et. al, 1978 , s. 25).

28 Termen 'kogebogslaboratorium' er hentet fra Kirschner (1992). 
Hvis kun den meningsfulde læring kan overføres og anvendes i nye sammenhænge, bliver det helt afgørende, at underviserne hjælper de (jura)studerende med at skabe overblik over, sammenhæng i og mening med det lærte.

I matematikdidaktikeren Guy Brosseaus (1997) model for didaktiske situationer i undervisningen identificerer Brosseau følgende fem faser i en undervisningssituation:

1) I devolutions-fasen overleverer underviseren problemet til de studerende (i eksemplet med glykogenøvelsen på DTU ovenfor svarer dette til at præcisere, at de studerende i denne laboratorieøvelse skal udvinde og analysere glykogen for at forstå, hvordan den menneskelige organisme udvinder energi fra kulhydrater).

2) I handlings-fasen handler de studerende, de arbejder med en opgave, en case, en laboratorieøvelse (de går i laboratoriet og snitter rottelever og udvinder glykogen).

3) I formulerings-fasen formulerer de studerende resultater (vi har udvundet så og så meget glykogen, der bliver nedbrudt i en sur hydrolyse på så og så lang tid).

4) I validations-fasen undersøger de studerende, om deres resultater er korrekte (ved at spørge hinanden og/eller underviserne og/eller slå efter i bøger eller tabeller).

5) I den afsluttende institutionalisations-fase samles der op og knyttes an til den indledende devolution (overlevering) af problemet; der skabes overblik over, sammenhæng i og mening med det lærte, der samtidig ekspliciteres; hvad viser og betyder dette, hvad har de studerende lært af dagens undervisning og/eller arbejdet med konkrete cases? (hvad har de studerende gjort i laboratoriet, hvilke resultater er de nået frem til, og - helt afgørende - hvad viser og betyder dette så, hvad har vi lært af dagens laboratorieøvelse om, hvordan den menneskelige organisme udvinder energi fra kulhydrater?).

I denne Brosseau-model kan skiftet i jurastuderendes læring fra overblik over til anvendelse af stoffet - og især de studerendes manglende overblik - forklares med, at de studerende hænger fast i opgaven (min formulering), de bliver fanget i de tre midterste faser (handlings-, formulerings- og validations-faserne), og mangler hjælp til at skabe mening i det lærte, ved eksempelvis at få formålet med case-arbejdet forklaret og gentaget.

De studerende på den nye studieordning giver stort set samstemmende udtryk for, at de gerne vil have (meget) mere traditionel katederundervisning med monologisk undervisergennemgang. Dette kan tolkes derhen, at de studerende ønsker mere mening og sammenhæng i det lærte. Men det kan dog også ses som udtryk for, at de 
studerende foretrækker den mere passive tilgang til læring, hvor underviseren giver dem svaret, uden at de selv skal arbejde for det. Et svar de studerende i øvrigt ikke kan bruge, fordi de ikke har oplevet nødvendigheden af og behovet for at kende - og finde - svaret.

I figur 3 nedenfor er studerendes traditionelle læring (1) markeret, tilsvarende er den nye anvendelsesorienterede, case-baserede læring markeret (2) med en yderligere markering (3) af, hvordan underviserne gerne skal hjælpe til at skabe overblik over, sammenhæng i og mening med det lærte.

Figur 3. Typer af læring - jurastuderendes læring ved traditionel udenadslære støttet af lærebogslæsning og monologisk undervisning (1) og ved case-arbejde (2) kombineret med underviserfokus på at skabe overblik over, sammenhæng i og mening med det lærte (3).

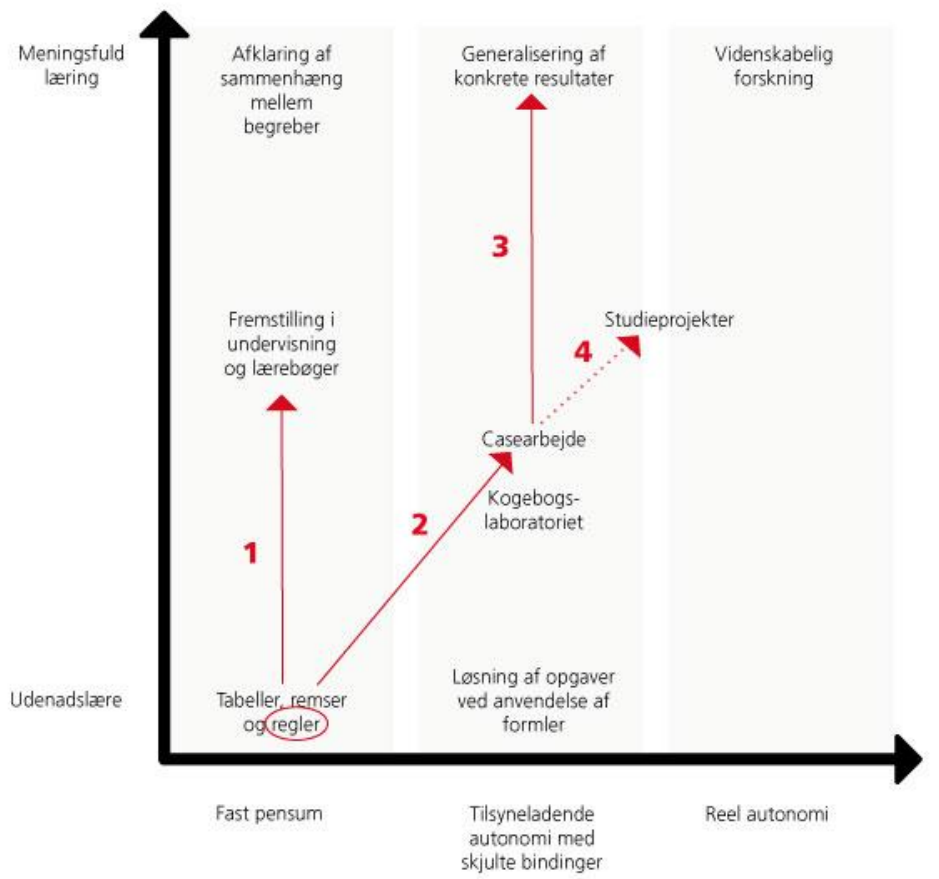

Kilde: Egen tilvirkning med udgangspunkt i Ausubel et al. (1978, s. 25).

\section{Opsamling, konklusion og perspektivering}

Et helt centralt element i studiereformen 2011 af jurastudiet ved Københavns Universitets Juridiske Fakultet er, at de studerende skal arbejde aktivt med stoffet - både før, under og efter den skemasatte undervisning.

Dette har ført til, at de studerende i højere grad end tidligere er velforberedte og tager aktivt, engageret og spørgelystent del i undervisningen. Desuden har de studerendes læringsmæssige udbytte ændret karakter: Hvor de studerende tidligere var orienteret mod detaljer, paratviden og udenadslære, har de studerende nu en bedre forståelse af stoffet, og er desuden blevet bedre til at anvende det lærte, ligesom de er blevet bedre til at reflektere, formulere sig og argumentere. 
Resultaterne fremlagt i denne artikel peger dog også på, at underviserne har en helt central rolle i forhold til at hjælpe de studerende med at skabe overblik over, mening med og sammenhænge i det lærte. I tilknytning hertil fremstår arbejdet med formulering af læringsmål og efterbehandlingsspørgsmål som helt centrale. Det er derudover afgørende, at underviserne ekspliciterer, hvad de studerende skal lære og har lært. De studerende kan ikke nødvendigvis udlede fra det konkrete, eksempelvis en case, til det generelle, men skal have hjælp til at forstå, hvad arbejdet med en konkret case illustrerer. Med Brousseaus termer svarer dette til at hjælpe de studerende til at forstå meningen med det lærte (ved særligt at fokusere på devolutions- og institutionaliseringsfaserne) for at undgå, at de studerende hænger fast i opgaven. En af undervisernes helt centrale opgaver er således at fokusere på devolutions- og institutionaliseringsfaserne: Hvordan hænger udvinding af glykogen fra rottelever sammen med den menneskelige organismens optag af kulhydrater? Hvilke juridiske grundfigurer og/eller generelle erstatningsretlige forhold er tilsvarende på spil og illustreres ved en case, hvor det konkrete spørgsmål kan være, om arbejdsgiver ifalder erstatningsansvar, når arbejdsgiverens bybud kommer til at ødelægge materiel ved levering af en vare?

Af figur 3 ovenfor fremgår det, at underviserne i forbindelse med såvel den traditionelle undervisning med læsning og monologiske undervisning (1) som den casebaserede undervisning ( 2 og 3 ) har en vigtig rolle i forhold til at supplere og stilladse$r e^{29}$ - ved at hjælpe de studerende med at skabe overblik over, sammenhæng i og mening med det lærte.

Min erfaring er imidlertid, at studerende - og mere generelt alle, der skal lære sig noget - i al sin enkelhed udelukkende lærer netop det, de øver sig på. Hvis man løser ligninger, bliver man bedre til at løse ligninger - uden at man nødvendigvis derved kan formulere ligninger. Hvis man slavisk følger øvelsesvejledninger i et laboratorium, bliver man god til at følge øvelsesvejledninger, uden at man nødvendigvis selv kan designe et eksperimentelt laboratorieforløb til at undersøge en relevant og interessant hypotese, man selv formulerer. Hvis jurastuderende læser afgørelser, bliver de bedre til at læse afgørelser, men de lærer kun at udforme lovbestemmelser ved netop at udforme - tænke over, diskutere og skrive - lovbestemmelser, ligesom de kun lærer at formulere og analysere retsvidenskabelige problemstillinger ved at gøre netop dette.

Hvis man skal kunne trække læring fra det konkrete til det generelle, kræver dette tilsvarende, at man øver sig på netop det.

29 Termen 'stilladsere' er en oversættelse af begrebet 'scaffolding' hentet fra læringsteoretikerne Jean Lave og Etienne Wengers bog (1991) om "Situated learning. Legitimate peripheral participation". 
En stor del af det, elever skal lære sig i skolastiske uddannelsessammenhænge, er, ligesom meget af det, jurastuderende skal lære sig, givet på forhånd. Dette kaldes læring af et fast pensum i figurerne 2 og 3 overfor. I skolastiske sammenhænge er det desuden ofte givet, hvordan bestemte typer af opgaver skal løses, ligesom svarene på de givne opgaver (ofte) er givet, hvorved opgaverne kan rettes - i modsætning til bedømmelse af videnskabelige opgaver - ved at klassificere svarene som rigtige eller forkerte. Dette svarer i Ellströms oversigt over typer af læring (jf. figur 4 nedenfor) til reproducerende læring.

Figur 4. Typer af læring - fra reproducerende til kreativ læring.

\begin{tabular}{|l|l|l|l|l|}
\hline & & \multicolumn{2}{|c|}{ Produktiv læring } & \\
\hline Læringssituationen & $\begin{array}{l}\text { Reproduce- } \\
\text { rende læring }\end{array}$ & $\begin{array}{l}\text { Regelstyret } \\
\text { læring }\end{array}$ & $\begin{array}{l}\text { Måstyret } \\
\text { læring }\end{array}$ & $\begin{array}{l}\text { Kreativ } \\
\text { læring }\end{array}$ \\
\hline Opgave & Givet & Givet & Givet & Ikke givet \\
\hline Metode & Givet & Givet & Ikke givet & Ikke givet \\
\hline Resultat & Givet & Ikke givet & Ikke givet & Ikke givet \\
\hline
\end{tabular}

Kilde: Ellström (1992, s. 71), egen oversættelse.

Ved udelukkende at arbejde med givne opgaver, der skal løses på bestemte måder for at nå frem til bestemte (de korrekte) resultater, lærer studerende sig netop dette.

Når fremtidens krav til juridiske kandidater imidlertid er ${ }^{30}$, at kandidaterne ikke kun skal kunne reproducere, men også i høj grad skal kunne håndtere, analysere og løse nye, komplekse problemer på nye, kreative måder, kræver det, at de studerende i løbet af deres studie øver sig på netop dette: Øver sig på selv at formulere problemer og projekter, der kan undersøges på forskellige måder og fører til forskellige analyser, vurderinger og konklusioner.

Med det videre arbejde med studiereformen af 2011 af den juridiske bachelor- og kandidatuddannelse bliver det derfor afgørende at finde måder, hvorpå de jurastuderende - ved eksempelvis at arbejde med Ellströms kreative læring via selvdefinerede 'Studieprojekter' (markeret med 4 i figur 3) - kan udvikle kompetencerne til at håndtere usikkerhed og kompleksitet, til at formidle, kommunikere og samarbejde og til - helt centralt - at identificere, analysere, ræsonnere, argumentere og løse nye (retsvidenskabelige) problemer på adækvate måder - de kompetencer, som samfundet, arbejdsmarkedet og aftagerne efterspørger.

30 Jf. eksempelvis oplæg ved censorformand og højesteretsdommer Jon Stokholm på Det Juridiske Fakultets censordag 15. marts 2012,

http://jura.ku.dk/pdf/uddannelsesservice/censor/censorarrangement_godkendt.pdf/ 
Pernille Rattleff (f. 1965) er uddannet cand. polit. og har en ph.d.-grad i uddannelsesvidenskab. Siden 1997 har Pernille forsket $i$ undervisning og lxring på universitetet, og har arbejdet med udvikling af universitetspædagogik og -didaktik på Danmarks Pædagogiske Universitet, Danmarks Tekniske Universitet og Københavns Universitet. Pr. 1. januar 2013 er Pernille Rattleff ansat som lektor i universitetspædagogik med særlig henblik på retsvidenskabelig uddannelse ved Det Juridiske Fakultet på Københavns Universitet.

\section{Referencer}

Andersen, H. L., \& Tofteskov, J. (2010). Eksamen og eksamensformer. Betydning og bedømmelse. Frederiksberg: Samfundslitteratur.

Ausubel, D. P. (1968). Educational psychology. A cognitive view. New York: Holt, Rinehart and Winston.

Ausubel, D. P., Novak, J. D., \& Hanesian, H. (1978). Educational psychology. A cognitive view. Second edition. New York: Holt, Rinehart and Winston.

Biggs, J. (2003). Teaching for Quality Learning at University. Berkshire: McGraw Hill.

Bloom, B. S., Engelhart, M. D., Furst, E. J., Hill, W. H., \& Krathwohl, D. R. (1956). Taxonomy of Educational Objectives The Classification of Educational Goals handbook 1: Cognitive Domain. New York: David McKay Company, Inc.

Brousseau, G. (1997). Theory of Didactical Situations in Mathematics. Dordrecht/Boston: Kluwer Academic Publishers.

Cornelius, H. \& Schnack, C. (1998). Voksenpædagogisk Opslagsbog. København: Christian Ejlers Forlag.

Det Juridiske Fakultets censordag 15. marts 2012. Udvalgte slides: http://jura.ku.dk/pdf/uddannelsesservice/censor/censorarrangement godkendt .pdf/ (tilgået 18.01.13).

Ellström, P.-E. (1992). Kompetens, utbildning och lärande i arbejdslivet. Problem, begrepp och teoretiska perspektiv. Stockholm: Norsted ts Juridik AB.

Fournais, A. A. (2012). Fagene på 1.år - og hvordan du består stopprøverne. http://www.studjur.dk/content/omjura/fagene.html (tilgået 10.05.12).

Grue-Sørensen, K. (1974). Almen pædagogik. En håndbog i de pædagogiske grundbegreber. København: Gjellerup.

Guilford, J. (1967). The Nature of Human Intelligence. New York: McGraw-Hill Book Company.

Jacobsen, B. (1989). Voksenundervisning og livserfaring. København: Christian Ejlers' Forlag.

Jarvis, P. (1990). An International Dictionary of Adult and Continuing Education. London and New York: Routledge.

Jarvis, P. (1992). Paradoxes of Learning. On Becoming an Individual in Society. San Francisco: Jossey-Bass Publishers.

Kirschner, P. A. (1992). Epistemology, Practical Work and Academic Skills in Science Education. I: Science E Education, 1 (s. 273-299).

Larsen, S. (1998). Den ultimative formel for læreprocesser. Hellerup: Eget Forlag. 
Lave, J., \& Wenger, E. (1991). Situated learning. Legitimate peripheral participation. Cambridge: Cambridge University Press.

Ministeriet for Forskning, Innovation og Videregående Uddannelser, Styrelsen for Universiteter og Internationalisering: Bologna-deklarationen.

http://www.iu.dk/politiske-rammer/bologna-processen (tilgået 18.01.13).

Ministeriet for Forskning, Innovation og Videregående Uddannelser, Styrelsen for Universiteter og Internationalisering: Kvalifikationsrammen for Livslang Læring. http://www.iu.dk/dokumentation/kvalifikationsrammer (tilgået 18.01.13).

Rattleff, P. (2001). Studiegruppers faglige diskussioner i computerkonferencer i et fjernstudium. Ph.d.-afhandling. København: Danmarks Pædagogiske Universitet.

Wahlgren, B., Høyrup, S., Pedersen, K., \& Rattleff, P. (2002). Refleksion og læring kompetenceudvikling $i$ arbejdslivet. København: Samfundslitteratur. 